\begin{tabular}{|c|c|}
\hline 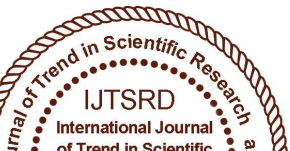 & $\begin{array}{l}\text { International Journal of Trend in Scientific } \\
\text { Research and Development (IJTSRD) }\end{array}$ \\
\hline $\begin{array}{lll} & \\
0\end{array}$ & International Open Access Journal \\
\hline and & ISSN No: $2456-6470$ | www.ijtsrd.com | Volume - 2 | Issue -3 \\
\hline
\end{tabular}

\title{
A Comprehensive Review of Applications of Stem Cell Therapy
}

\author{
Vanshita $^{1}$, Jashika ${ }^{1}$, Puneeta Ajmera ${ }^{2}$, Sheetal Yadav ${ }^{2}$, Harish K. Satia ${ }^{3}$, Mahavir Singh ${ }^{4}$ \\ ${ }^{1}$ Student, Dept. of Hospital \& Healthcare Management, Amity University, Haryana, India \\ ${ }^{2}$ Assistant Professor, Dept. of Hospital Administration, Amity University, Haryana, India \\ ${ }^{3}$ Prof. \& HOD, Dept. of Hospital Administration, Amity University, Haryana, India \\ ${ }^{4}$ Prof. \& HOI, Amity Medical School, Amity University, Haryana, India
}

\section{ABSTRACT}

Stem cells are those cells which have the capability to develop into other different types of cells of our body like RBC, WBC etc. Most of the cells which are present in the human body are differentiated cells. Differentiated cells are those cells which perform a specific function only. Recently, stem cells have been used with the therapeutic intention of regenerating damaged tissues. In the present paper we have reviewed current fundamental concepts regarding applications of stem cells in different parts of human body. We have also discussed various studies which have already been conducted by different researchers on the latest applications and dimensions of stem cell therapy.

\section{INTRODUCTION}

Stem cells are those cells that haven't differentiated yet. They have the ability to divide themselves and make infinity copies of themselves. Though other cells present in the human body also have replication ability but this repletion ability is only for a limited number before they begin to break down. On the other hand, stem cell divide and they can remain as a stem cell or they can develop into other differentiated cells like liver cell muscle cell.

According to Jacquelyn Cafasso (Chan, Su et al. 2017) stem cells are those cells which have the capability to develop into other different types of cells of our body like RBC, WBC etc. Most of the cells which are present in the human body are differentiated cells. Differentiated cells are those cells which perform a specific function only. For example, as we know that all human beings start out as only one cell. This cell is known as the zygote. The zygote divides by mitosis process. Then the cells begin to differentiate and perform specific functions of the body. This process is known as differentiation.

Generally, there are three types of stem cells:

1. Adult stem cells

\section{Embryonic stem cells}

3. Induced pluripotent stem cells

Adult stem cells are basically undifferentiated cells which are present in our bodies. These cells renew themselves or generate new cells. Adult stem cells are also called as somatic stem cells. These cells can also repair other cells of our bodies. Hematopoietic stem cells, mesenchymal stem cells, neural stem cells, epithelial stem cells, skin stem cells are the types of adult stem cells

Embryonic stem cells are derived from the inner cell mass of an embryo at the blastocyst stage. These cells are also called as pluripotent stem cells. These cells have the potential to develop into any type of cell that is found during the first stage of development but not the placenta and umbilical cord. These cells are very precious because they provide renewable resources for normal development, cure diseases and for other therapies. 
Induced pluripotent stem cells are artificial stem cells which are created in a laboratory. These are the medium between embryonic stem cells and adult stem cell. These cells are like embryonic stem cells. Generally, these cells are tools, to learn about normal development and diseases. They are also helpful for developing and testing new drugs and therapies. The characteristics of these cells are similar to embryonic stem cells as mentioned above so that they can ultimately be used as the source of cells or tissues for medical treatment.

\section{Background of study}

In 1800 , it was discovered by Robert hooke that cells are the basic unit of life and in animals and humans, some cells are present which have the ability to produce other cells (Nurse 2003). In early 1900, it was discovered that in human body some cells are present which have the ability to generate blood cell. This statement is proofed by an attempt of the fertilized mammalian egg outside the human body (Elgert 2009). In 1968, first bone marrow transplant was performed successfully (Bach, Albertini et al. 1968). In 1978, human cord blood stem cells were discovered by Dr Gregor Pindul. Human cord blood stem cells are also used as alternative source of embryonic stem cell. According to the present researchers, these are used in human stem cell therapy(Prindull and Prindull 1978).

In 1981, embryonic stem cell was identified in mice by Martin Events and first in-vitro stem cell line was developed in mice (Thomson, Itskovitz-Eldor et al. 1998). In 1988, embryonic stem cell line was discovered in a hamster (Doetschman, Williams et al. 1988). In 1995, first embryonic stem cell line was developed from a primate. In 1997, at Roslin Institute, Wilmut and his colleagues discovered dolly, the sheep which is the first artificial animal clone. To discover this animal clone, they fused a sheep egg with an udder cell (it is an organ which is formed in the mammary gland of a female having four-legged mammals) and then implanted the resulting hybrid egg into a surrogate mother sheep. Through this process, the researcher found that the similar hybrids which are made by fusing human embryonic stem cell with an adult cell from a human being can be used to develop genetically matched tissue and organs.(Nerlich, Clarke et al. 2001)

In 1998, James Thomson, from early embryos isolated the cells and developed the first embryonic stem cell
lines(Thomson, Itskovitz-Eldor et al. 1998). After this, John Gearhart derived the germs cells from foetal gonad tissue and from both the resources, pluripotent stem cell lines were discovered. In 1999 and 2000 it was discovered that adult stem cells can produce different types of cells like red blood cells, white blood cells etc.(Wagers and Weissman 2004) In 2000 the National Institute of Health released the guidelines for use of embryonic stem cells in research i.e., that the scientists can use only extra embryos and they receive federal funding(Perry 2000).

In January 2002 National Academy of Science completely banned the human reproductive cloning. But it supported therapeutic cloning for medical purposes only(Walters 2004). In February 2002, cloning of human embryos were banned. In July 200,2 the President's council on bio-ethics recommended a four-year ban on cloning for medical research to allow time. In February 2005, Hwang Woo Suk successfully created stem cell cloning with the help of therapeutic cloning(Hwang, Roh et al. 2005).

In January 2009, Geron tested embryonic stem cell therapy on 8-10 patients suffering from severe spinal cord injuries. This was the world's first experiment of a therapy derived from a human embryonic stem cell on humans. In October 2010 Geron Corp. sponsored the first injection of cells from human embryonic stem cell for clinical trials on humans(Stewart and Bertuch 2010). In May 2011, stem cell therapy was used in sports medicines in which bone marrow stem cells were injected into injured elbow and shoulders(DeChellis and Cortazzo 2011).

In February 2012, John Hopkins proved that a patient's own stem cells can be used to regenerate heart tissues to cure damage caused by heart attack. This was the first instance of therapeutic regeneration.(Needham, Davidson et al. 2012) In May 2013, human skin cells scientists made the first embryonic stem cell by reprogramming human skin cells.

In April 2014, scientists were able to use cloning techniques for stem cells for the first time to generate stem cells that are genetically matched to adult patients(Shlush, Zandi et al. 2014). In October 2014, stem cells were transplanted into 18 blind patients(Pagliuca, Millman et al. 2014). 


\section{Applications of stem cell therapy:}

Stem cells which are collected from the umbilical cord are special. These are young, potent, and viable. A large number of clinical studies are conducted by researchers that stem cells are suitable for regeneration of damaged tissue after accidents, degenerative diseases like e.g. slipped intervertebral discs or cancer treatment. Umbilical cord blood and tissue are rich in the stem cell. These are used as an important therapeutic option in future medicine. Stem cells are used in the treatment of some serious diseases from last 55 years. These are used especially in the treatment of cancer which require the high dose of chemotherapy. The patient's own stem cells are extracted from their bone marrow or peripheral blood which are stored temporarily and transplanted into the patient after chemotherapy to reduce the side effects of chemotherapy and it also helps to regenerate the destroyed cells of patients.

\subsection{Placental tissue}

Placental tissues have the remarkable potential to develop into different types of cells which are present in our body during early life and growth. These tissues are used in regenerative medicines. Generally, it is observed that placental tissues have a three-layer structure. These three layers of tissues are originated from the fetus and the mother which contains a large number of cells. Donors of placental tissue are free from any physical dangers. It is necessary to match a variety of HLA types of patients and donors. Mesenchymal cells are derived from decidua i.e.DMCs (it is a uterine thick layer of the modified mucous membrane), as well as Mesenchymal cells, are also derived from bone marrow i.e. BM-MSCs. Mesenchymal cells which are derived from decidua having high proliferative fibroblast than mesenchymal cells which are derived from bone marrow. With the help of retroviral transfer of factor genes, DMCs generates the induced pluripotent stem. As we have discussed above DMCs are derived from the mother or we can say that it is derived from the maternal portion of the placenta, so these have the ethical advantages for cell banking because they can be collected with the full consent of the adult donor. They are also useful for generation of human iPS for regenerative applications. (Doucet, Ernou et al. 2005)

\subsection{Therapy Targeting Stem Cell in Patients with Decompensated Cirrhosis of Liver in a Tertiary Treatment}

Hepatic failure has only a curative treatment and that is liver transplantation but this curative treatment has high cost and is limited by less chances of survival. Another method discovered for management of decompensated cirrhosis is liver support device (MARS). This is a therapeutic device which help to perform the function of liver for hepatic failure patients. MARS stands for the Molecular Adsorbent Recirculating System. However, research has shown that MARS does not reduce mortality rate as compared to the standard medical treatment. We know that stem cells have great potential to differentiate into other multiple cells. During liver regeneration, bone marrow generates hematopoietic stem cells which contribute to the proliferation of stem cells; therefore these are beneficial for liver regeneration in patients with decompensated cirrhosis of the liver.(Al Mahtab, Alam et al. 2017)

\subsection{Regenerative Medicine and Disease Therapeutics}

Recently, regenerative medicines have emerged with the medical sciences which deal with the functional restoration of tissues or cells or organs for the patients which suffering from severe injuries or chronic disease. In the field of stem cell research, it is found that the diseases which cannot be cured by conventional medicines these types of diseases can be cured by cell-based therapies. The special character of stem cell i.e. indefinite self-renewal and potential to differentiate into another cell, this special character represent stem cell as frontiers of regenerative medicine. The ex-vivo remodelling of stem cells grown into 3D organoids and tissue structure for personalized application due to the advancement of gene editing and tissue engineering technology. In regenerative medicines, the most recent advancements are in transplantation and tissue engineering technologies of ESCs, TSPSCs, MSCs, UCSC's, BMSCs andiPSCs. (Mahla 2016)

\subsection{Adult stem cell therapy and heart failure}

Heart failure is very common and highly destructive disease that causes significant morbidity and mortality. Coronary artery disease (CAD), valvular heart disease, and other cardiac disorder can cause heart failure. Stem cell regenerative medicines are the therapeutic strategy to repair or replace injured and nonviable myocardium. With the results of the inconclusive study, it is proofed that stem cell regenerative capacity and ability can improve cardiac 
functions. There are three basics mechanisms which show that stem cell therapy can be used as an effective treatment for heart failure.

1. As we have discussed above that stem cell have the ability to generate new cells, adult stem cells could generate new cardiac cells or tissues, and this process is called as cardiogenesis.

2. The second proposed mechanism is that by activating endogenous endothelial progenitor cells, (EPC) the stem cells generate vascularate via angiogenesis or vasculogenesis.
3. Only a subset of EPCs is true endothelial lineage which is capable of neovasculogenesis. Mounting evidence suggests that adult stem cells have cardioprotective factor. This secreted factor may stimulate the vascular growth and remodelling, modulate inflammation, and regulate cell differentiation and survival. According to recent studies, it is concluded that these factors form clusters of extracellular membrane vesicles which includes exosomes and microsomes than these aretransferred into proteins, lipids, RNA and micro RNA to mediate cardio protection.(Nguyen, Rhee et al. 2016)

\section{Potential U.S. patiet population for}

\section{Stem cell based therapies}

\begin{tabular}{|c|c|}
\hline Medical condition $\mathrm{SCl}$ & entiff Number of patients \\
\hline Cardivascular diease & 58 million \\
\hline Auto-immune diease & 30 million \\
\hline Diabetes & 16 million \\
\hline Ostoporosis Internat & lal Journal 10 million \\
\hline Cancer of Trend in & Scientific 8.2 million \\
\hline Alzheimer's dieases Resea & ch and 5.5 million \\
\hline Parkinson's disease & 5.5 million \\
\hline Burns (severe) & 0.3 million \\
\hline Spinal cord injuries & $50=04 / 0 \quad 0.25$ million \\
\hline Birth defects & 0.5 million $/$ year \\
\hline
\end{tabular}

Source : derived from the National Academy of sciences web site (Manual 2000)

\section{Literature review on stem cells}

\begin{tabular}{|l|l|l|l|}
\hline S.no & \multicolumn{1}{|c|}{ Research Area } & \multicolumn{1}{|c|}{ Researcher } & \multicolumn{1}{|c|}{ Year } \\
\hline $\mathbf{1 .}$ & $\begin{array}{l}\text { Reflection on the governance of clinical stem cell } \\
\text { researchand applications in China }\end{array}$ & Chen, Haidan \\
\hline $\mathbf{2 .}$ & $\begin{array}{l}\text { Stem cell-derived organoids and their application } \\
\text { for medical research and patient treatment }\end{array}$ & $\begin{array}{l}\text { Sina Bartfeld, } \\
\text { Hans Clever }\end{array}$ & 2017 \\
\hline $\mathbf{3 .}$ & $\begin{array}{l}\text { A new approach in stem cell research-Exosomes: } \\
\text { Their mechanism of action via cellular pathways }\end{array}$ & $\begin{array}{l}\text { Derkus, B. } \\
\text { Emregul, K. C. } \\
\text { Emregul }\end{array}$ & 2017 \\
\hline
\end{tabular}


International Journal of Trend in Scientific Research and Development (IJTSRD) ISSN: 2456-6470

\begin{tabular}{|c|c|c|c|}
\hline 4. & $\begin{array}{l}\text { Latest developments in the field of stem cell } \\
\text { research and regenerative medicine compiled from } \\
\text { publicly available information and press releases } \\
\text { from nonacademic institutions }\end{array}$ & $\begin{array}{l}\text { Stem Cell Laboratories, } \\
\text { Guy's Assisted } \\
\text { Conception Unit, } \\
\text { Department of Women \& } \\
\text { Children's Health, Faculty } \\
\text { of Science \& Medicine, } \\
\text { King's College London, } \\
\text { London, UK. }\end{array}$ & 2017 \\
\hline 5. & $\begin{array}{l}\text { Induced pluripotent stem cells in Parkinson's } \\
\text { disease: scientific and clinical challenges }\end{array}$ & $\begin{array}{l}\text { Bin Xiao1, } \\
\text { Huck Hui Ng2,3, } \\
\text { Ryosuke Takahashi4, } \\
\text { Eng-King Tan1 }\end{array}$ & 2016 \\
\hline 6. & Cryopreservation and banking of dental stem cells & $\begin{array}{l}\text { Hilkens, Petra } \\
\text { Driesen, Ronald B } \\
\text { Wolfs, Esther } \\
\text { Gervois, Pascal } \\
\text { Vangansewinkel, Tim } \\
\text { Ratajczak, Jessica } \\
\text { Dillen, Yörg } \\
\text { Bronckaers, Annelies } \\
\text { Lambrichts, Ivo }\end{array}$ & 2016 \\
\hline 7. & $\begin{array}{l}\text { Advances in Applications of Metabolomics in } \\
\text { Pluripotent Stem Cell Research }\end{array}$ & $\begin{array}{l}\text { Vijesh J. Bhute, Xiaoping } \\
\text { Bao, and Sean P. Palecek }\end{array}$ & 2016 \\
\hline 8. & Stem-cell therapy for cardiac disease & $\begin{array}{l}\text { Vincent F. M. } \\
\text { Segers\& Richard T. Lee }\end{array}$ & 2008 \\
\hline 9. & $\begin{array}{l}\text { Single Lgr5 stem cells build crypt-villus } \\
\text { structures in vitro without a mesenchymal niche }\end{array}$ & $\begin{array}{l}\text { Toshiro Sato, Robert G. } \\
\text { Vries, Hugo J. } \\
\text { Snippert, Marc van de } \\
\text { Wetering, Nick } \\
\text { Barker, Daniel E. } \\
\text { Stange, Johan H. van } \\
\text { Es, Arie Abo, Pekka } \\
\text { Kujala, Peter J. } \\
\text { Peters \& Hans Clevers }\end{array}$ & 2005 \\
\hline 10. & $\begin{array}{l}\text { Searching for an unrelated haemopoietic stem cell } \\
\text { donor--a United Kingdom perspective }\end{array}$ & $\begin{array}{l}\text { O'Shea, J. } \\
\text { Cleaver, S. } \\
\text { Little, A. M. } \\
\text { Madrigal, A. }\end{array}$ & 1999 \\
\hline 11. & $\begin{array}{l}\text { Treatment of multicentric Castleman's disease } \\
\text { complicated by the development of non-Hodgkin's } \\
\text { lymphoma with high-dose chemotherapy and } \\
\text { autologous peripheral stem-cell support }\end{array}$ & $\begin{array}{l}\text { Advani, R. } \\
\text { Warnke, R. } \\
\text { Rosenberg, S. }\end{array}$ & 1999 \\
\hline 12. & 4 Primate Embryonic Stem Cells & $\begin{array}{l}\text { James } \\
\text { A.ThomsonVivienne } \\
\text { S.Marshall }\end{array}$ & 1997 \\
\hline 13. & $\begin{array}{l}\text { Genetically selected cardiomyocytes from } \\
\text { differentiating embronic stem cells form stable } \\
\text { intracardiac grafts. }\end{array}$ & $\begin{array}{l}\text { M G KLUG, M H } \\
\text { SOONPAA, G Y } \\
\text { KOH, AND L J FIELD }\end{array}$ & 1996 \\
\hline
\end{tabular}


International Journal of Trend in Scientific Research and Development (IJTSRD) ISSN: 2456-6470

\begin{tabular}{|l|l|l|l|}
\hline $\mathbf{1 4 .}$ & $\begin{array}{l}\text { Embryonic Stem Cells Express Neuronal } \\
\text { Properties in Vitro }\end{array}$ & $\begin{array}{l}\text { Gerard BainDaniel } \\
\text { KitchensMinYaoJames } \\
\text { E.HuettnerDavid } \\
\text { I.Gottlieb }\end{array}$ & 1995 \\
\hline $\mathbf{1 5 .}$ & $\begin{array}{l}\text { Multiple hematopoietic lineages develop from } \\
\text { embryonic stem (ES) cells in culture }\end{array}$ & M.V. Wiles, G. Keller & 1991 \\
\hline $\mathbf{1 6 .}$ & $\begin{array}{l}\text { Formation of germ-line chimaeras from embryo- } \\
\text { derived teratocarcinoma cell lines }\end{array}$ & $\begin{array}{l}\text { Allan Bradley, Martin } \\
\text { Evans, Matthew H. } \\
\text { Kaufman \& Elizabeth } \\
\text { Robertson }\end{array}$ & 1984 \\
\hline $\mathbf{1 7 .}$ & $\begin{array}{l}\text { Isolation of a pluripotent cell line from early mouse } \\
\text { embryos cultured in medium conditioned by } \\
\text { teratocarcinoma stem cells }\end{array}$ & G R Martin & 1981 \\
\hline
\end{tabular}

\section{Discussion}

This paper aims to discuss the significance of stem cells. Stem cells therapy have been investigated and tried on various parts of the human body and it is proved that stem cells are useful for replacement of various defective/damaged organs. The self renewing and differentiating potentials of stem cells have a unique property of plasticity. However, its use is being studied by various scientists in various fields so as to reproduce new organs, tissues or cells. In this paper we have discussed about the various applications of stem cells to cure dieases.Although treatments that use a patient's own stem cells might dramatically solve the crucial problems of donororgan scarcity, high cost, and allograft rejection, these treatments are still highly experimental.

According to recent article of Times of India i.e, 'functional mini-kidney' grown from stem cells."mini-kidney"- these are capable of filtering blood to produce urine. They have been grown in a living organism. This is the major steps towards treatment of kidney disease. Reaserchers have been able to develop human stem cells into mini-kidney. It is complete with functioning human blood vessels and able to filter the blood.

As biological discoveries identify key factors for stem cells survival and technological advances provide new biomatiarels, the potential for improved treatment is dramatic. In conclusion, stem cells therpy can be utilized greatly to treat and manage diseases. More studies are needed in human stem cells to understand its significance.

\section{References}

1) Advani, R., et al. (1999). "Treatment of multicentric Castleman's disease complicated by the development of non-Hodgkin's lymphoma with high-dose chemotherapy and autologous peripheral stem-cell support." Annals of oncology 10(10): 1207-1209.

2) Al Mahtab, M., et al. (2017). "Therapy Targeting Stem Cell in Patients with Decompensated Cirrhosis of Liver in a Tertiary Treatment Care Center of Bangladesh." Euroasian journal of hepato-gastroenterology 7(1): 113.

3) Bach, F., et al. (1968). "Bone-marrow transplantation in a patient with the WiskottAldrich syndrome." The Lancet 292(7583): 13641366.

4) Bain, G., et al. (1995). "Embryonic stem cells express neuronal properties in vitro." Developmental biology 168(2): 342-357.

5) Bartfeld, S. and H. Clevers (2017). "Stem cellderived organoids and their application for medical research and patient treatment." Journal of Molecular Medicine 95(7): 729-738.

6) Bhute, V. J., et al. (2017). "Advances in applications of metabolomics in pluripotent stem cell research." Current opinion in chemical engineering 15: 36-43.

7) Bradley, A., et al. (1984). "Formation of germ-line chimaeras from embryo-derived teratocarcinoma cell lines." Nature 309(5965): 255.

8) Chan, Z., et al. (2017). "Cellco: Portable Device for Automated Blood Cell Count and Abnormal Cell Detection." Journal of Telecommunication, 
Electronic and Computer Engineering (JTEC) 9(39): 119-122.

9) DeChellis, D. M. and M. H. Cortazzo (2011). "Regenerative medicine in the field of pain medicine: Prolotherapy, platelet-rich plasma therapy, and stem cell therapy-Theory and evidence." Techniques in Regional Anesthesia \& Pain Management 15(2): 74-80.

10) Derkus, B., et al. (2017). "A New Approach in Stem Cell Research-Exosomes: Their Mechanism of Action Via Cellular Pathways." Cell biology international.

11) Doetschman, T., et al. (1988). "Establishment of hamster blastocyst-derived embryonic stem (ES) cells." Developmental biology 127(1): 224-227.

12) Doucet, C., et al. (2005). "Platelet lysates promote mesenchymal stem cell expansion: A safety substitute for animal serum in cell-based therapy applications." Journal of cellular physiology 205(2): 228-236.

13) Elgert, K. D. (2009). Immunology: understanding the immune system, John Wiley \& Sons.

14) Hilkens, P., et al. (2016). Cryopreservation and banking of dental stem cells. Biobanking and Cryopreservation of Stem Cells, Springer: 199235.

15) Hwang, W. S., et al. (2005). "Patient-specific embryonic stem cells derived from human SCNT blastocysts." Science 308(5729): 1777-1783.

16) Klug, M. G., et al. (1996). "Genetically selected cardiomyocytes from differentiating embronic stem cells form stable intracardiac grafts." The Journal of clinical investigation 98(1): 216-224.

17) Mahla, R. S. (2016). "Stem cells applications in regenerative medicine and disease therapeutics." International journal of cell biology 2016.

18) Manual, H. C. (2000). "Transportation research board." National Research Council, Washington, DC 113: 10.

19) Martin, G. R. (1981). "Isolation of a pluripotent cell line from early mouse embryos cultured in medium conditioned by teratocarcinoma stem cells." Proceedings of the National Academy of Sciences 78(12): 7634-7638.

20) Needham, D. M., et al. (2012). "Improving longterm outcomes after discharge from intensive care unit: report from a stakeholders' conference." Critical care medicine 40(2): 502-509.

21) Nerlich, B., et al. (2001). "Fictions, fantasies, and fears: The literary foundations of the $\mathrm{cl}$ oning debate." Journal of Literary Semantics 30(1): 3752.

22) Nguyen, P. K., et al. (2016). "Adult stem cell therapy and heart failure, 2000 to 2016: a systematic review." JAMA cardiology 1(7): 831841.

23) Nurse, P. (2003). "The great ideas of biology." Clinical medicine 3(6): 560-568.

24) O'Shea, J., et al. (1999). "Searching for an unrelated haemopoietic stem cell donor--a United Kingdom perspective." Clinical transplants: 129137.

25) Pagliuca, F. W., et al. (2014). "Generation of functional human pancreatic $\beta$ cells in vitro." Cell 159(2): 428-439.

26) Perry, D. (2000). "Patients' voices: the powerful sound in the stem cell debate." Science 287(5457): 1423-1423.

27) Prindull, ficG. and B. Prindull (1978). "Haematopoietic stem cells (CFUc) in human cord blood." Acta Paediatrica 67(4): 413-416.

28) Sato, T., et al. (2009). "Single Lgr5 stem cells build crypt-villus structures in vitro without a mesenchymal niche." Nature 459(7244): 262.

29) Segers, V. F. and R. T. Lee (2008). "Stem-cell therapy for cardiac disease." Nature 451(7181): 937.

30) Shlush, L. I., et al. (2014). "Identification of preleukaemic haematopoietic stem cells in acute leukaemia." Nature 506(7488): 328.

31) Stewart, S. A. and A. A. Bertuch (2010). The role of telomeres and telomerase in cancer research, AACR.

32) Thomson, J. A., et al. (1998). "Embryonic stem cell lines derived from human blastocysts." Science 282(5391): 1145-1147.

33) Thomson, J. A. and V. S. Marshall (1997). 4 Primate Embryonic Stem Cells. Current topics in developmental biology, Elsevier. 38: 133-165.

34) Wagers, A. J. and I. L. Weissman (2004). "Plasticity of adult stem cells." Cell 116(5): 639648. 
35) Walters, L. (2004). "Human embryonic stem cell research: an intercultural perspective." Kennedy Institute of Ethics Journal 14(1): 3-38.

36) Wiles, M. V. and G. Keller (1991). "Multiple hematopoietic lineages develop from embryonic stem (ES) cells in culture." Development 111(2): 259-267.

37) Xiao, B., et al. (2016). "Induced pluripotent stem cells in Parkinson's disease: scientific and clinical challenges." J Neurol Neurosurg Psychiatry: jnnp2015-312036. 